\title{
Study of Integrated Pest Management Strategy on The Population of Fruit Flies (Bactrocera spp.) in Red Chili Cultivation (Capsicum Annuum)
}

\author{
Wildan Muhlison*, Nanang Tri Haryadi, Agung Sih Kurnianto, Bugar Syarif Ahmada \\ Department of Agrotechnology, Faculty of Agriculture, University of Jember, Indonesia
}

\begin{abstract}
The fruit fly Bactrocera spp. is the main pest other than Thrips in red chilies, which can reduce plant productivity by $30-$ $60 \%$, so that a specific method of handling this pest is needed. This study examines the application of conventional and Integrated Pest Management (IPM) strategies to fruit fly populations in red chili cultivation (Capsicum annuum). Observation of fruit fly population used the comparative method with methyl eugenol traps and incubation of infected fruit. Determination of the research sample based on purposive sampling method and analyzed using descriptive analysis. The test parameters were the fruit fly population indicated by the host's density and hosts' availability in the applied IPM and conventional treatments. The results showed that the fruit fly species encountered were dominated by B. dorsalis with a percentage of $98.18 \%$ and B. carambola $1.82 \%$. The fruit fly population's fluctuation in IPM and conventional treatments were significantly different, as evidenced by a one-way variance test at a significance level of $99 \%$. The population of fruit flies in the IPM concept was 547 flies, while the conventional concept was 1546 flies. The percentage of fruit fly population in red chili plants with IPM treatment was $48 \%$ smaller than conventional treatments.
\end{abstract}

Keywords: Bactrocera spp., IPM, Population, Red chilies.

\section{INTRODUCTION}

The fruit fly Bactrocera spp. is the main pest after thrips on red chili plants, which reduced plant productivity by $30-60 \%$ [1]. In the initial attack, the larvae of Bactrocera spp. shows no symptoms, looks healthy and intact from the outside. After a few days, the fruit will change color to yellowish-red, and when viewed from the inside, there is a larvae of Bactrocera spp. Red chilies were attacked by Bactrocera spp. result in the fruit not being harvested because it will be fall out before it can be harvested. Bactrocera spp. was also included in the quarantine pest to watch out for and become one of the obstacles in chilies production [2]. The technique for controlling Bactrocera spp. has been done by control using synthetic pesticides. Insecticides with various frequencies do not affect the level of fruit fly pests [3]. The application of insecticides in controlling fruit fly pests is not effective because the larval phase is in the fruit tissue.

One approach in managing pests in cultivated crops is to implement Integrated Pest Management (IPM). The IPM can be interpreted as a pest management strategy oriented towards prevention and control by integrating all compatible techniques based on ecological principles [4]. Pest control techniques widely developed in IPM strategies are habitat

\footnotetext{
${ }^{*}$ Correspondence address:

Wildan Muhlison

Email : wildan.muhlison@unej.ac.id

Address : Dept. Agriculture, University of Jember, Sumbersari, Jember, 68121
}

manipulation by combining several companion plants and applying botanical pesticides.

Plantations managed with IPM and conventional strategies affect pest populations. It was reported that the intensity of Aphid attack on conventional treatments was higher than the IPM treatment on red chili plants [5]. Other studies have also shown that the thrips population is higher in conventional treatment than in IPM treatment [6]. However, the application of the IPM strategy on the population of fruit fly pests in red chili plants is not yet known. Therefore, it is necessary to research IPM strategies on fruit fly populations in red chili cultivation. This study aimed to determine the population of fruit flies in red chili cultivation managed by the IPM strategy.

\section{MATERIAL AND METHOD}

The materials used in this research are large red chilies of the Imola variety, organic fertilizers, chemical fertilizers, botanical pesticides, synthetic pesticides, alcohol, Turnera subulata, Methyl Eugenol, fruit fly traps, and incubation boxes. This research was conducted in the area of the red chili cultivation center in Andongsari Village, Ambulu District, Jember Regency. The research was carried out on red chili cropping areas with integrated and conventional pest management (IPM) treatments. In IPM land, the management techniques applied are refugia planting and application of botanical pesticides. In conventional land, the management technique applied is the application of synthetic pesticides. The following is a table of the components of the management (Table 1). 

(Muhlison, et al.)

Table 1. Management technique components

\begin{tabular}{|c|c|c|}
\hline $\begin{array}{l}\text { Treatment } \\
\text { Components }\end{array}$ & IPM & Conventional \\
\hline $\begin{array}{l}\text { Companion } \\
\text { planting }\end{array}$ & Turnera subulata & --- \\
\hline Pesticide & $\begin{array}{l}\text { Botanical pesticide } \\
\text { (soursop, papaya, } \\
\text { and neem leaf) }\end{array}$ & $\begin{array}{l}\text { Abamectin, } \\
\text { Dimethoate, } \\
\text { Imidacloprid, } \\
\text { Cypermethrin }\end{array}$ \\
\hline $\begin{array}{l}\text { Time of } \\
\text { pesticide } \\
\text { application }\end{array}$ & $\begin{array}{l}\text { Once a week (start } \\
21-67 \text { days after } \\
\text { planting) }\end{array}$ & $\begin{array}{l}\text { Once a week or } \\
\text { anytime }\end{array}$ \\
\hline
\end{tabular}

\section{Population of Fruit Flies}

This activity consists of two movements, namely taking samples using attractant traps and taking samples by incubating the affected fruit (Fig. 1). The attractant trapping was carried out by sampling using the Methyl Eugenol attractant trap, each trap was given 3-4 drops of ME on cotton and $1 \%$ formalin [7]. The trapping is installed in the morning at $06.00-09.00$ West Indonesian Time. This sampling was carried out once a week during the generative phase with one-week intervals. The catch was collected, and the trapped fruit fly population was counted every week.

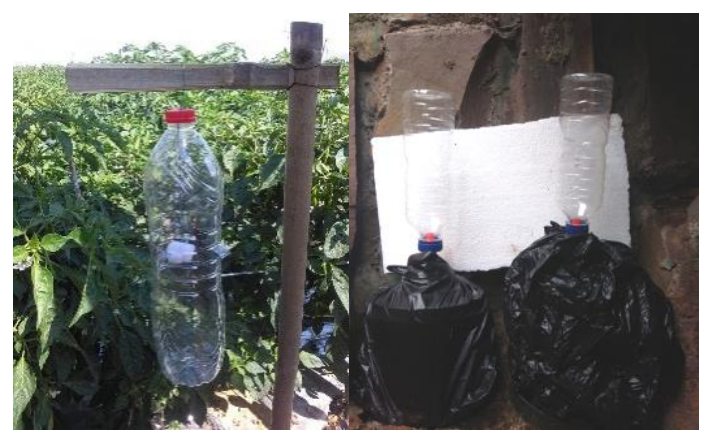

Figure 1. Attractant traps and Fruits incubation box
Incubation of infected fruit was carried out by taking red chili fruit samples by purposive sampling with criteria of approximately $15-17 \mathrm{~cm}$ long with a diameter of 1.4-1.6 cm, reddish-green to red in color. This sampling was carried out once a week during the generative phase (10-19 WAP). As many as 20 pieces of fruit were taken each week on different plants, which were then incubated. The fruit flies and parasitoids that came out of the incubator were then collected, and the population counted.

\section{Identification of Fruit flies}

Identification was carried out at the Agrotechnology Laboratory, Faculty of Agriculture, University of Jember. Observations were made using the identification of fruit fly [8].

\section{RESULT AND DISCUSSION Population of Bactrocera spp.}

Population of Bactrocera spp. obtained from traps and incubation of infected fruit every week of observation showed that the population of Bactrocera spp fluctuated and increased at each stage of plant age growth. The lowest population was found at 10 weeks after plantation (WAP) observations, while the highest population was found at 19 WAP observations. The chili plants aged 10 WAP entered the early harvest period of red chili plants so that the number of red chilies was still small and most of the fruit had not yet entered the physiological maturity phase, so the population of Bactrocera spp was still low. In the 19 weeks of observation, the availability of red chilies is in abundance. In addition, the data collection of infected fruit did not show any parasitoids that had appeared.

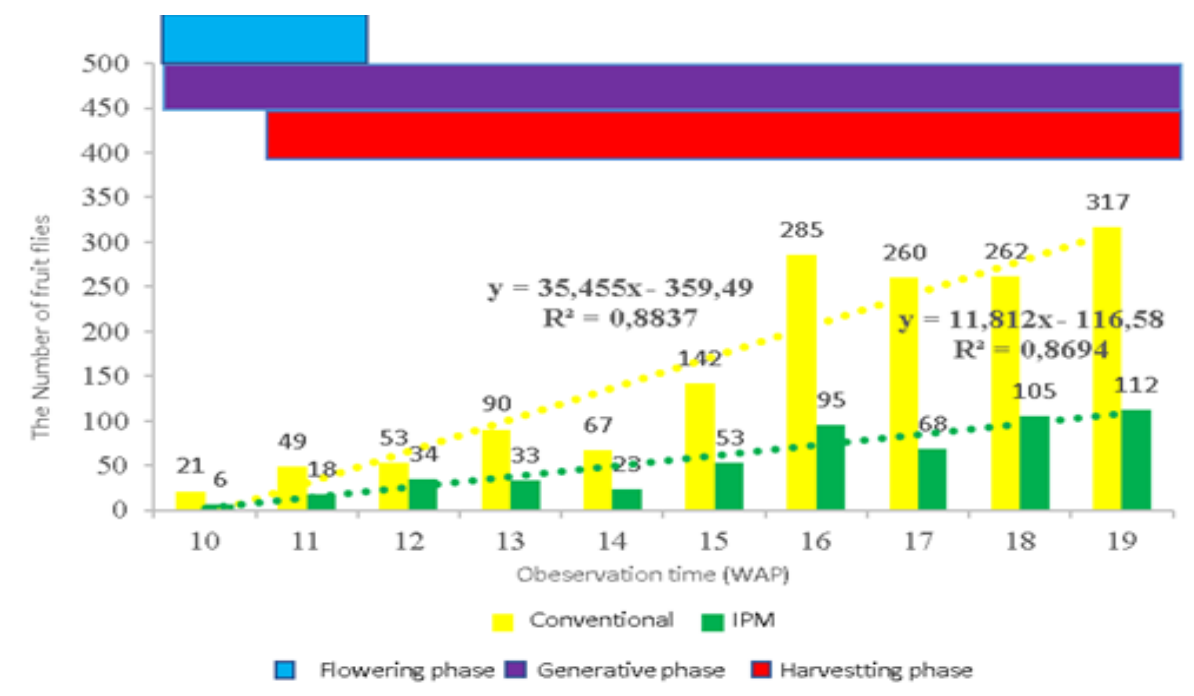

Figure. 2. Fluctuations of fruit flies' population in IPM and conventional treatments at each plant age development 
The results of observations of the fruit fly population at each plant phenology development showed that the high number of fruit fly populations in the field started from 10-19 WAP and continued to increase in each phase, especially in the $14^{\text {th }}$ phase of the WAP, which entered the harvest phase. The population of Bactrocera spp. in these two treatments continued to increase with the plant's age (Fig. 2). The increase in plant age is related to the increase in the number of chilies. It is in line with the number of harvests per week, which continues to increase up to 20 WAP. The population of C. capitata is fundamentally influenced by the abundance and level of fruit maturity [9]. Besides, the presence of host plants and availability of hosts is one of the main factors for fruit fly populations [10].

Based on table 2, the total number of fruit flies in conventional treatment was higher and significantly different from the IPM treatment. One of the IPM strategy components is planting companion plants, namely $T$. subulata as a border. One form of the polyculture planting system is companion planting. Planting of $T$. subulata in oil palm plantations could reduce pest populations and attract natural enemies such as predators and parasitoids. T. subulata around oil palm plants can increase the number of parasitized pests so that the pest population density can be reduced [11,12].

Various research results indicate that the intercropping cropping pattern is effective in reducing pest attacks in the agroecosystem. Volatile compounds of cultivated and noncultivated plants could inhibit pest behavior in finding host plants and reduce the rate of attack by these pests [13]. Companion plant planting can affect the pest population in an ecosystem. The intercropping of potatoes and celery could reduce Trips by $44 \%$ and Myzus persicae aphids by $55.6 \%$ on potato crops [14]. The factors that make cultivation vulnerable to pest attack include a decrease in landscape and plant diversity, pesticides, unbalanced fertilization, and climate change [15].

The population percentage of Bactrocera spp. in the red chili plantations that were treated with IPM is $26 \%$, while in the conventional treatment, it was $74 \%$ (Fig. 3). Companion planting between the main crop and refugia can interfere with the discovery of host sites by pests, draw pests from protection targets, repel pests, cover the main crop, and camouflage the main crop or physically deter pests [13].
Table 2. The total population of fruit flies in each treatments

\begin{tabular}{clc}
\hline No & Treatments & $\begin{array}{c}\text { number of fruit flies } \\
\text { (head) }\end{array}$ \\
\hline 1 & IPM & $547 \mathrm{~b}$ \\
2 & Conventional & $1546 \mathrm{a}$ \\
\hline & P-value & 0.009 \\
\hline
\end{tabular}

Note: Numbers followed by different letters in the same column show a significant difference in the t-test $=1 \%$

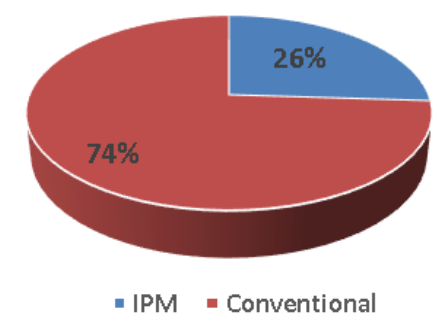

Figure 3. Percentage of total fruit flies' population in each IPM and conventional treatment

In addition to the influence of companion plants, the effect of botanical pesticide application is assumed to affect fruit fly populations on IPM treated land. It is because botanical pesticides can be used, among others, as a pest control agent, which kills pests quickly, acts as a substance that inhibits the development of insects or pests, and acts as an attractive agent, repellent substance, and food inhibitor. Botanical pesticides include plants matter (refined extraction), which can function as a killer, binding agent, and inhibitor of plant pests' growth [16]. Botanical ingredients were used soursop leaves and gadung tubers (Dioscorea hispida), which act as insecticides, larvacides, repellents, and antifeedants. Soursop leaves contain acetogenin compounds, including asimycin, roundacin, and squamosin, which function as pest repellents and anti-food items [17]. Soursop leaf extracts starting at a concentration of $2.5 \%$ have anti-eating activity and reduce the relative consumption rate and the relative growth rate of $S$. litura instar V [18].

\section{Percentage of fruit fly species}

The fruit fly species found in the red chili fields in Andongsari Village are Bactrocera dorsalis and B. carambola, $98.18 \%$ and $1.82 \%$, respectively (Fig. 4). B. dorsalis dominated the dominant fruit flies in red chili cultivation in Bandung Regency at $93 \%$. B. dorsalis is the main pest of red chilies and dominates other fruit fly species [19].

The dominant population of $B$. dorsalis is because this insect is invasive and competitive 
with other fruit flies and its host range is quite broad so that it becomes the dominant fruit fly species in cultivated crops, especially horticultural crops $[20,21]$. B. dorsalis has high reproductive power, wide distribution, high roaming ability, and polyphages [22]. In Indonesia, the fruit fly $B$. dorsalis (sin. Bactrocera papayae) is reported to attack chili plants, either Capsicum annuum or Capsicum frutescens $[23,24]$.

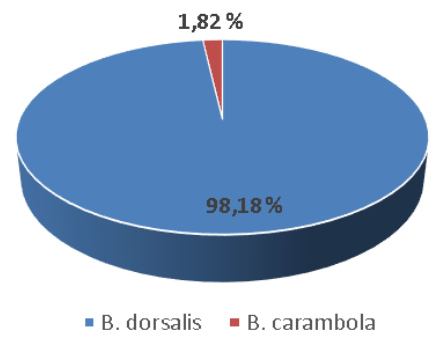

Figure 4. The percentage composition of the fruit fly species $B$. dorsalis and B. Carambola

\section{CONCLUSION}

The results showed that the fruit fly species encountered were dominated by $B$. dorsalis with a percentage of $98.18 \%$ and $B$. carambola $1.82 \%$. Fruit fly populations in IPM and conventional treatments were significantly different as evidenced by a one-way variance test at a significance level of $99 \%$. The population of fruit flies in the IPM concept was 547 flies, while the conventional concept was 1546 flies. The percentage of fruit fly population in red chili plants with IPM treatment was $48 \%$ smaller than conventional treatment.

\section{REFERENCES}

[1] Mayasari, I., Y. Fitriana, L. Wibowo, Purnomo. 2019. Efektifitas metil eugenol terhadap penangkapan lalat buah pada pertanaman cabai di Kabupaten Tanggamus. J. Agrotek Tropika. 7(1). 231 238.

[2] Sarango, V.M.G. 2009. Monitoring and pest control of Fruit flies in Thailand: new knowledge for integrated pest management. Master Thesis. Swedish University of Agricultural Sciences.

[3] Labany, M.M.E. 2017. hubungan antara cara-cara budidaya tanaman cabai dengan keadaan serangan lalat buah dan penyakit oleh virus. Bachelor Thesis. Bogor Agricultural University. Bogor.

[4] Mudjiono, G. 2013. Pengelolaan Hama Terpadu: konsep, taktik, strategi, penyusunan program PHT, dan implementasinya. UB Press. Malang.

[5] Nugroho, Y., G. Mudjiono, and R.D. Puspitarini. 2013. Pengaruh sistem Pengendalian Hama Terpadu (PHT) dan non PHT terhadap tingkat populasi dan intensitas serangan Aphid (Homoptera: Aphididae) pada tanaman cabai merah. Jurnal HPT. 1(3). 85- 95.

[6] Sugiyono, B.R., G. Mudjiono, R. Rachmawati. 2014. Studi kelimpahan populasi Thrips sp. pada perlakuan Pengelolaan Hama Terpadu dan konvensional pada tanaman cabai (Capsicum snnuum L.) di Desa Bayem Kecamatan Kasembon Kapubaten Malang. Jurnal HPT. 2(2). 67-78.

[7] Susanto, A., F. Fathoni, N.I.N. Atami, Tohidin. 2017. Fluktuasi populasi lalat buah (Bactrocera dorsalis Kompleks.) (Diptera: Tephritidae) pada pertanaman pepaya di Desa Margaluyu, Kabupaten Garut. Jurnal Agrikultura. 28(1). 32-38.

[8] Larasati A., P. Hidayat dan D. Buchori. 2016. Kunci Identifikasi Lalat Buah (Diptera: Tephritidae) di Kabupaten Bogor dan Sekitarnya. Jurnal Entomologi Indonesia. 13(1). 49-61.

[9] Radonjic, S., M. Čizmović, R Pereira. 2013. Population dynamics of the mediterranean fruit fly in Montenegro. Int. J. Insect Sci. 5(1). 35-40.

[10] Sciarretta, A., P. Trematerra. 2010. Spatiotemporal distribution of Ceratitis capitata population in a heterogeneous landscape in central Italy. J. Appl. Entomol. 135(4). 241251.

[11] Hidayat, R., C. Irsan, A. Setiawan. 2018. Diversity of phytophagous and entomophagous insect on yellow alder flower (Turnera subulata J.E SM and Turnera ulmifolia L.) around the palm oil (Elaeis guineensis J.). Science and Technology Indonesia. 3(3). 130-133.

[12] Sheteven, S. Tarmadja, I.S. Santi. 2018. Kepadatan populasi musuh alami berdasarkan jarak tanaman sumber pakan. Jurnal Agromast. 3(1). 1-7.

[13] Parker, J.E., W.E Snyder, G.C. Hamilton, C.R. Saona. 2013. Companion planting and insect pest control. The State University of New Jersey.

[14] Sutrisna, N., S. Sastraatmadja, I. Ishaq. 2005. Kajian sistem penanaman tumpang sari kentang (Solanum tuberosum L.) di lahan 
Dataran Tinggi Rancabali, Kabupaten Bandung. Jurnal Pengkajian dan Pengembangan Teknologi Pertanian. 8(1). 78-87.

[15] Nurindah. 2006. Pengelolaan agroekosistem dalam pengendalian hama. Perspektif. 5(2). 78-85.

[16] Haerul, M.I. Idrus, Risnawati. 2016. Efektifitas pestisida nabati dalam mengendalikan hama pada tanaman cabai. Jurnal Agrominansia. 1(2). 129-136.

[17] Tenrirawe, A., M.S. Pabbage. 2007. Pengendalian penggerek batang jagung (Ostrinia furnacalis G.) dengan ekstrak daun sirsak (Annona muricata L.). Proceeding of Scientific Seminar and Annual Meeting PEI and PFI XVIII, Komda South Sulawesi. Balai Penelitian Tanaman Sereal. Maros.

[18] Ambarningrum, T.B., E.A. Setyowati, P. Susatyo. 2012. Aktivitas anti makan ekstrak daun sirsak (Annona muricata L.) dan pengaruhnya terhadap indeks nutrisi serta terhadap struktur membran peritrofik larva instar V Spodoptera litura F. Jurnal HPT Tropika. 12(2). 169-176.

[19] Saputra, H.M., Sarinah, M. Hasanah. 2019. Kelimpahan dan dominansi lalat buah (Diptera: Tephritidae) pada pertanaman cabai (Capsicum annuum L.), di Desa Paya Benua, Bangka. Agrosainstek. 3(1). 36-41.

[20] Vargas, R.I., R.L. Mau, E.B. Jang. 2007. The hawaii fruit fly area-wide pest management program: accomplishments and future directions. Proc. Hawaiian Entomol. Soc. 39. 99-104.

[21] Vayssieres, J.F., M. de Meyer, I. Ouagoussounon, A. Sinzogan, A. Adandonon, S. Korie, R. Wargur, F. Anato, H. Houngbo, C. Didier, H. de Bon, G. Goergen. 2015. Seasonal abundance of mango fruit flies (Diptera: Tephritidae) and ecological implications for their management in mango and cashew orchards in Benin (Centre \& North). J. Econ. Entomol. 108(5). 2214-2230.

[22] Vargas, R.I., J.C. Piñero, L. Leblanc. 2015. An overview of pest species of Bactrocera fruit flies (Diptera: Tephritidae) and the integration of biopesticides with other biological approaches for their management with a focus on the pacific region. Insects. 6(2). 297-318.

[23] Larasati A., P. Hidayat, D. Buchori. 2013. Keanekaragaman dan persebaran lalat buah Tribe Dacini (Diptera: Tephritidae) di
Kabupaten Bogor dan sekitarnya. Jurnal Entomologi Indonesia. 10(2). 51-59.

[24] Khaeruddin. 2015. Identifikasi lalat buah (Diptera: Tephritidae) di beberapa Kabupaten di Provinsi Sulawesi Barat. Master Thesis. Faculty of Agriculture, Bogor Agricultural University. Bogor. 